\title{
PERAN BRAND TRUST DALAM MEMEDIASI BRAND EXPERIENCE, BRAND PERSONALITY DAN BRAND COMMUNITY TERHADAP BRAND LOYALTY
}

\author{
Alifah Ratnawati \\ Annisa Ayu Lestari \\ Universitas Islam Sultan Agung Semarang \\ sayaannis@yahoo.co.id
}

\begin{abstract}
This study aims to know and analyze the influence of brand experience, brand personality and brand community to brand loyalty with brand trust as a variable intervening on Oriflame products .. The population is the consumer who ever bought the product Oriflame in Semarang, with the number of samples of 100 respondents. The sampling technique used in this research is convenience sampling or convenience.. The analysis tool is path analysis, where previously tested the validity and reliability as well as the classical assumption test. Test results show that brand experience, brand personality and brand personality proved to have a significant positive effect on brand trust and brand loyalty. Brand trusts have a positive influence on brand loyalty. Brand trust can be an intervening variable between brand experience and brand personality toward brand loyalty. Brand trust can be an intervening variable between brand community towards repurchase meaning higher brand community, the more consumers can strengthen the understanding of its members due to high trust to Oriflame brand, so that will increasingly increase customer loyalty to the brand.
\end{abstract}

Keywords: Brand experience, brand personality, brand community, brand trust brand loyalty

\section{PENDAHULUAN}

Merek memegang peranan penting karena mengembangkan suatu merek akan terkait dengan janji dan harapan, sehingga salah satu perannya adalah menjembatani harapan konsumen saat kita menjanjikan sesuatu kepada konsumen. Hal ini sesuai dengan pendapat Davis (2000) dalam Yasri, dkk (2014) bahwa merek adalah sekumpulan janji, merek menyatakan secara tidak langsung tentang kepercayaan (trust) dan konsistensi (consistency). Produk yang memiliki ekuitas merek yang kuat akan mampu mengembangkan landasan merek yang kuat sehingga konsumen akan tetap loyal dalam menggunakan produk tersebut Loyalitas konsumen terhadap merek merupakan ukuran keterkaitan pelanggan kepada sebuah merek. Ukuran loyalitas mampu memberikan gambaran tentang mungkin tidaknya seorang pelanggan beralih ke merek produk lain Keunggulan terhadap produk yang ditawarkan akan menambah tingkat loyalitas pelanggan, sehingga akan menimbulkan tingginya brand trust dari pelanggan. Konsumen yang loyal adalah konsumen yang terus melakukan pembelian ulang dan mempunyai antusiasme untuk memperkenalkannya kepada siapapun yang konsumen kenal. Konsumen yang loyal disebabkan karena tingginya kepercayaan terhadap produk yang digunakan, sehingga semakin tinggi kepercayaan konsumen terhadap merek suatu produk, maka tentu 
akan semakin menambah tingginya loyalitas konsumen. Hal ini sesuai pernyataan Griffin dalam Bastian (2014) menjelaskan bahwa loyalitas konsumen lebih dikaitkan dengan kepercayaan konsumen terhadap suatu merek produk..

Begitu pula dengan produk-produk merek Oriflame, yaitu merek yang menjual produk kecantikan. Dalam usaha meningkatkan pasar, perusahaan Oriflame terus melakukan inovasi-inovasi terhadap produk-produk yang ditawarkan, seperti yang terlihat pada produk perawatan rambut dan pribadi, Men care, wewangian, perawatan kulit, makeup yang begitu banyak variasinya. Oriflame menawarkan berbagai macam produk perawatan dan kecantikan tubuh dari bahan alami untuk para konsumennya.

Dalam upaya meningkatkan loyalitas pelanggan, perusahaan Oriflame memiliki keunggulan dalam penjualan produk yaitu dengan mengadopsi sistem Network Marketing atau MLM dan tetap mengedepankan kualitas dan mutu terjamin dengan harga terjangkau. Sistem penjualan langsung yang ditawarkan Oriflame memberikan keuntungan baik untuk pelanggan maupun Oriflame Consultant sendiri. Untuk pelanggan, sistem ini menawarkan cara yang nyaman, menyenangkan, dan dapat diandalkan untuk berbelanja melalui teman dengan tipstips pribadi, ide dan inspirasi, serta jaminan uang kembali. Hal yang melatarbelakangi permasalahan bahwa strategi yang diterapkan perusahaan tersebut belum mampu meningkatkan loyalitas pelanggan.

Penelitian tentang brand loyalty telah banyak dilakukan, seperti yang dilakukan oleh Mulyadi dan Saktiawati (2013) dan Yasri dan Sylvia (2014) menyatakan bahwa brand personality mempunyai pengaruh terhadap loyalitas pelanggan. Akan tetapi hasil penelitian yang dilakukan oleh Brody dan Cunningham, 1968; Enggel, et al, (1969) menjelaskan bahwa brand personality tidak memiliki pengaruh kuat pada perilaku loyalitas konsumen, namun lebih merupakan suatu situasi terikat.

Hasil penelitian Azize Sahin et al (2011) dan Kusuma (2014) menunjukkan bahwa Brand experience dan brand trust berpengaruh terhadap brand loyalty, sedangkan pada penelitian Ramaseshan dan Stein (2014) menyatakan jika brand personality berpengaruh terhadap brand loyalty, sedangkan Brand experience justru tidak berpengaruh terhadap brand loyalty. Hasil penelitian Atmaja dan Rachmawaty (2016) menunjukkan bahwa komunitas merek dan kepercayaan merek berpengaruh terhadap loyalitas merek.

Hasil penelitian Denkala dan Tricahyono (2016) menunjukkan bahwa komunitas merek berpengaruh terhadap loyalitas pelanggan. Sedangkan hasil penelitian Dewi dan Sampurno (2015) bahwa brand personality tidak berpengaruh terhadap brand loyalty sedangkan kepercayaan berpengaruh terhadap brand loyalty. Hasil penelitian Ramadhania dan Suryadi (2011) tejadi sebaliknya bahwa komunitas merek tidak berpengaruh terhadap loyalitas merek.

Berdasarkan hasil penelitian tersebut menunjukkan kontradiksi antara peneliti satu dengan lainnya, terutama pada variable Brand experience, brand personality dan brand community dalam mempengaruhi brand loyalty. Untuk itu dalam penelitian ini akan menguji kembali dengan mengacu pada penelitian terdahulu yang hasilnya masih inkonsisten.

Berdasarkan latar belakang masalah dijelaskan bahwa terjadi penurunan loyalitas pelanggan terhadap merek Oriflame, terbukti dengan menurunnya penjualan perusahaan. Hal tersebut juga dibuktikan dengan terjadinya kontradiksi antara penelitian satu dengan lainnya. Dengan perumusan masalah tersebut yaitu bagaimana upaya yang dilakukan pihak manajemen perusahaan agar loyalitas pelanggan terhadap produk Oriflame dapat meningkat, sehingga pertanyaan penelitian adalah bagaimana pengaruh brand experience, brand personality dan brand 
community terhadap brand loyalty dengan brand trust sebagai variable intervening pada produk Oriflame?

\section{KAJIAN PUSTAKA \\ Brand Loyalty}

Menurut Oliver (2009) loyalitas adalah komitmen yang dipegang secara mendalam untuk membeli atau berlangganan bagi produk atau jasa tertentu di masa depan meskipun ada pengaruh situasi dan usaha pemasaran yang berpotensi menyebabkan peraliharan perilaku. Sedangkan Tjiptono (2012) menjelaskan loyalitas konsumen sebagai komitmen konsumen terhadap suatu merek, toko atau pemasok berdasarkan sifat yang sangat positif dalam pembelian jangka panjang.

Engel, Blackwell dan Miniard (1995) dalam Wahyuni (2014) mendefinisikan loyalitas sebagai perilaku pembelian pengulangan yang menjadi kebiasaan konsumen, dimana ada keterkaitan dan keterlibatan tinggi pada pilihan konsumen terhadap pada obyek tertentu serta lebih bercirikan dengan ketiadaan pencarian informasi eksternal dan evaluasi alternative. Loyalitas sebagai perilaku untuk melakukan pembelian secara berulang-ulang dan untuk membangun loyalitas pelanggan terhadap produk/jasa yang dihasilkan sehingga akan membentuk waktu yang lama melalui proses pembelian yang berulang-ulang (Olson, Trisno Musanto 2004).

Faktor-faktor yang menentukan konsumen loyal yaitu faktor kepercayaan bisa jadi disadari saat kita memahami komponen-komponen kepercayaan ini dan menerapkannya dalam kehidupan seharihari. Keterlibatan terjadi saat peduli dan tertarik dengan bisnis dan masalahnya. Indikator tingkat kepercayaan dalam suatu bisnis mencakup kualitas hubungan, mitra yang adil dan kredibelitas (Suddin Lada, dkk, 2014). Kepercayaan bermula dari ditepatinya kata-kata. Hasil kepercayaan dari meletakkan minat konsumen terlebih dahulu, menjadi tergantung, terbuka dan memberikan informasi yang relevan. Tidak mungkin untuk melebih-lebihkan kekuatan faktor kepercayaan dalam kehidupan profesional kita. Sebenarnya, kepercayaan adalah dasar dari hubungan bisnis jangka panjang dan langgeng.

Konsumen akan setia terhadap merek sangat bergantung pada kemampuan manajemen perusahaan dalam mengelola indiaktor yang menentukan kesetiaan merek. Strategi yang berlaku sekarang merupakan usaha perusahaan dalam persaingan dengan menggunakan kesempatan atau peluang pasar melalui usaha membina dalam menentukan indikator kesetiaan konsumen terhadap merek, antara lain melalui tingkat kepuasan (satisfaction), kebiasaan menggunakan produk (habitual behavior), komitmen (commitment), dan tingkat kesukaan pada merek (liking of the brand) (Kusuma, 2014).

Memiliki pelanggan yang loyal adalah suatu hal yang sangat berharga bagi perusahaan. Beberapa karakteristik konsumen yang loyal menurut Griffin (2012), dapat dijelaskan sebagai indikator brand loyalty antara lain melakukan pembelian secara teratur/berulang, membeli diluar lini produk atau jasa, merekomendasikan produk kepada orang lain dan menunjukan kekebalan dari daya tarik produk atau jasa sejenis dari pesaing

\section{Brand Experience}

Menurut Brakus et al.(2009) Brand experience merupakan sensasi, perasaan, kognisi dan tanggapan konsumen yang ditimbulkan oleh merek, terkait rangsangan yang ditimbulkan oleh desain merek, identitas merek, komunikasi pemasaran, orang dan lingkungan merek tersebut dipasarkan. Sedangkan Brakus et al. (2009) menjelaskan brand experience dilihat dari sudut pandang konsumen dengan menguji pengalaman-pengalaman konsumen itu sendiri dan bagaimana pengalaman itu menghasilkan pendapat sikap, dan aspek lainnya dari perilaku konsumen. 
Brand experience bergantung pada kepercayaan dan kepuasan konsumen atas kebutuhannya (Tempral, 2001). Kebutuhan tersebut termasuk kebutuhan fungsional yang terpenuhi dengan pembelian produk, juga kebutuhan emosional yang diperoleh pelanggan berupa stimulasi terhadap emosi dan perasaannya yang dipenuhi oleh merek. Brand experience akan semakin berkesan apabila memiliki perbedaan dari competitor, dan disampaikan dengan jelas. Menurut Temporal (2001) bagi konsumen, Brand experience yang baik lebih dari sekedar kualitas dan fungsi. Brand experience akan menjadi sumber bagi konsumen atas terciptanya brand trust dan hal ini akan mempengaruhi brand loyalty (Ferrinadewi, 2008).

Menurut Brakus et al. (2009) terdapat 4 dimensi Brand experience, yaitu sensorik. Dimensi sensorik, yaitu dimensi yang menciptakan pengalaman melalui penglihatan, suara, sentuhan, bau, dan rasa. Afeksi. Dimensi afeksi, yaitu pendekatan perasaan dengan mempengaruhi suasana hati, perasaan dan emosi. Perilaku. Dimensi perilaku, yaitu menciptakan pengalaman secara fisik, pola perilaku, gaya hidup. Intelektual. Dimensi intelektual, yaitu menciptakan pengalaman yang mendorong konsumen terlibat dalam pemikiran seksama mengenai keberadaan suatu merek

\section{Brand Personality}

Menurut Aaker (1997) mendefinsiikan brand personality sebagai kumpulan dari karakteristik manusia yang dikaitkan dalam sebuah merek dengan menggambarkan bagaimana konsumen mengekspresikan dirinya. Brand personality dapat digunakan sebagai salah satu cara untuk membedakan merek terhadap pesaingnya. Kepribadian menjadi semacam pembeda yang membuat diri kita unik dan mudah diingat orang lain. Untuk membedakan produk yang dihasilkan produk pesaing, perusahaan melakukan penambahan nilai-nilai personality pada merek. Jadi fungsi merek bukan sekedar gambaran tentang produk, merek merupakan wakil pribadi penggunanya, dan nilai suatu merek berubah dari instrumental menjadi simbolik, yaitu yang dapat mengekspresikan pemakainya (Rangkuti, 2012).

Kotler dan Keller (2009) menyatakan bahwa para pemasar dituntut untuk mengetahui perilaku konsumennya. Salah satu faktor penentu perilaku konsumen yaitu faktor pribadi, yang mencakup usia dan siklus hidup, pekerjaan dan lingkungan ekonomi, kepribadian dan konsep diri, juga gaya hidup dan nilai. Pemanfaatan personalitas merek sebagai upaya dalam membedakan merek terhadap pesaingnya akan lebih efektif pada merek yang secara fungsi atau fisik sangat sulit dibedakan antara satu dan lainnya. Dengan demikian brand personality merupakan salah satu identitas dari merek agar membangun hubungan emosional kepada konsumen dan dengan personalitas merek dapat membedakan suatu merek terhadap merek pesaingnya.

Terdapat lima indikator brand personality yang dikemukakan oleh Kotler \& Amstrong (2012) antara lain sincerity (ketulusan), excitement (semangat), competence (kemampuan), sophistication (eksklusifitas) dan ruggedness (ketangguhan).

\section{Brand Community}

Muniz dan O'Guinn (2001) dalam Atmaja dan Rachmawaty (2016) mendefinisikan komunitas merek sebagai bentuk komunitas yang terspesialisasi, memiliki ikatan yang tidak berbasis pada ikatan secara geografi namun lebih didasarkan pada seperangkat struktur hubungan sosial diantara penggemar merek tertentu. Sedangkan Schouten \& Mc. Alexander (1995) mendefinisikan komunitas merek sebagai kelompok sosial yang berbeda yang dipilih secara pribadi berdasarkan pada persamaan komitmen terhadap kelas produk tertentu, merek dan aktivitas konsumsi.

Butscher (2006) mendefinisikan brand community sebagai kumpulan orang atau organisasi yang saling berkomunikasi, yang 
diprakarsai dan dioperasikan oleh suatu organisasi untuk berhubungan dengan anggotanya secara langsung dan teratur serta menawarkan paket manfaat yang dianggap bernilai tinggi dengan tujuan mengaktifkan anggotanya dan meningkatkan loyalitasnya dengan menciptakan hubungan emosional. Tanggung jawab moral adalah perasaan tanggung jawab terhadap komunitas secara keseluruhan dan anggota individu dari komunitas tersebut.

Muniz dan O'Guinn (2001) menjelaskan bahwa komunitas merek (brand community) terdiri dari 3 komponen, diantaranya adalah Kesadaran bersama (consciousness of kind), Ritual dan tradisi dan Rasa Tanggung Jawab Moral (Moral responsibility).

Kesadaran bersama (consciousness of kind), lebih mengacu pada hubungan intrinsik dan perasasan kolektif diantara para anggota dan sekaligus merasakan perbedaan dengan mereka yang tidak termasuk anggota komunitas. Consciousness of kind juga mencakup rasa kepemilikan komunitas dari orang yang mempunyai ketertarikan yang sama. Kesadaran bersama (consciousness of kind) terdiri dari 2 unsur yaitu legitimasi merupakan proses dimana anggota komunitas membedakan antara anggota komunitas dengan bukan anggota komunitas memiliki hak yang berbeda. Kedua adalah loyalitas merek oposisi merupakan proses sosial yang terlibat selain kesadaran masyarakat atas suatu jenis produk. Melalui oposisi dalam kompetisi merek, anggota komunitas merek mendapat aspek pengalaman yang penting dalam komunitasnya, serta komponen penting pada arti merek tersebut.

Ritual dan tradisi, dalam hal ini mewakili proses sosial yang penting dimana arti dari komunitas adalah mengembangkan dan menyalurkan dalam komunitas. Ritual dan tradisi dipusatkan pada pengalaman dalam menggunakan merek dan berbagi cerita pada seluruh anggota komunitas. Seluruh komunitas merek bertemu dalam suatu proyek yang terdapat beberapa bentuk upaya atau tradisi. Ritual dan tradisi dikelompokkan dalam indikator merayakan sejarah merek (celebrating the history of the brand) dan berbagi cerita merek (sharing brand stories)

Rasa Tanggung Jawab Moral (Moral responsibility), ditandai dengan tanggung jawab moral bersama secara keseluruhan serta kepada setiap anggota komunitas. Rasa tanggung jawab moral adalah hasil kolektif yang dilakukan dan memberikan kontribusi pada rasa kebersamaan dalam kelompok. Rasa tanggung jawab moral terdiri dari indikator integrasi dan mempertahankan anggota (integrating and retaining members), meliputi mempertahankan anggota lama dan mengintegrasikan baru dan membantu penggunaan merek (assisting in the use of the brand), meliputi membantu anggota lain dalam penggunaan merek

\section{Brand Trust}

Kepercayaan merek (brand trust) adalah kemampuan merek untuk dipercaya (brand reliability), yang bersumber pada keyakinan konsumen bahwa produk tersebut mampu memenuhi nilai yang dijanjikan dan intensi baik merek (brand intention) yang didasarkan pada keyakinan konsumen bahwa merek tersebut mampu mengutamakan kepentingan konsumen (Delgado dalam Ferrinnadewi, 2008).

Brand trust akan mempengaruhi customer loyalty dengan pertimbangan brand trust memiliki peran yang penting bagi produk. Delgado (dalam Ferinnadewi, 2008) menjelaskan bahwa brand trust merupakan harapan akan kehandalan dan intensi baik merek. Dengan demikian komponen penting dari brand trust yang pertama yakni, keyakinan konsumen bahwa produk tersebut mampu memenuhi nilai yang dijanjikan atau dengan kata lain persepsi bahwa merek tersebut mampu memenuhi harapan konsumen dengan terpenuhinya janji merek yang pada akhirnya menciptakan customer satisfaction, yang kedua, keyakinan konsumen bahwa merek tersebut mampu 
mengutamakan kepentingan konsumen ketika masalah dalam konsumsi produk muncul secara tidak terduga.

Menurut lien (2009) menjelaskan bahwa keberhasilan membangun kepercayaan dibangun dari empat tindakan: keterlibatan, mendengarkan, penyusunan, dankomitmen. Faktor kepercayaan bisa jadi disadari saat kita memahami komponen-komponen kepercayaan ini dan menerapkannya dalam kehidupan sehari-hari. Keterlibatan terjadi saat peduli dan tertarik dengan bisnis dan masalahnya. Indikasi tingkat kepercayaan dalam suatu bisnis mencakup kualitas hubungan, mitra yang adil dan kredibilitas, Chtman (1994) dalam Carissa, dkk (2014).

Menurut Dooney dan Connon (1997) dalam Carissa (2014) brand trust dapat diukur dengan beberapa faktor, antara lain memberikan informasi yang benar, rasa percaya dalam memenuhi janjinya dan rasa percaya bahwa produk yang ditawarkan aman atau tidak beresiko.

Menurut Lau \& Lee (1999), terdapat tiga faktor sebagai pengukur kepercayaan terhadap merek, antara lain Brand Characteristic, Company Characteristic dan Consumer-Brand Characteristic.

\section{Hubungan Antar Variabel \\ Pengaruh Brand Experience terhadap Brand Trust}

Konsumen mempunyai kepercayaan terhadap merek suatu produk disebabkan karena pengalaman konsumen dalam menggunakan suatu produk yang dibelinya. Dalam brand trust, seorang konsumen memiliki hubungan personal yang tinggi terhadap suatu merek produk karena pengalamannya selama menggunakan produk tersebut sesuai dengan yang diharapkan (Siahaan, 2011). Seberapa besar pengalaman orang menggunakan merek suatu produk, maka tentu akan mengetahui kelebihan yang dimiliki suatu produk sehingga akan menambah tingginya kepercayaan orang tersebut. Brand experience akan semakin berkesan apabila memiliki perbedaan dari competitor, dan disampaikan dengan jelas. Brand experience akan menjadi sumber bagi konsumen atas terciptanya brand trust dan hal ini akan mempengaruhi brand loyalty (Ferrinadewi, 2008).

Hasil penelitian Puspitasari (2015) menyatakan bahwa Brand experience berpengaruh positif terhadap brand trust. Hasil penelitian serupa juga dilakukan oleh Dewanti, dkk (2010) dan Lodjo (2013) yang menyatakan bahwa Brand experience berpengaruh terhadap brand trust produk. Berdasarkan kajian terhadap studi-studi empiris, diajukan hipotesis sebagai berikut.

$\mathrm{H}_{1}$ : Brand experience berpengaruh terhadap brand trust

\section{Pengaruh Brand Personality terhadap Brand Trust}

Untuk dapat membangun merek yang baik, para pemasar hendaknya mengerti dan memahami keunikan pada merek tersebut. Salah satu hal unik yang dimiliki oleh merek adalah kepribadian merek. Setiap jenis produk memiliki kepribadian yang berbeda dan ingin mewakili setiap tipe konsumen yang berbeda atau untuk situasi yang berbeda. Kepercayaan konsumen terhadap suatu merek akan tinggi dan berusaha untuk mencari produk jika produk tersebut sesuai dengan kepribadian yang mendekati kemiripan atau kesesuaian dengan diri mereka Merek yang memiliki brand personality yang unggul dan sesuai dengan personality konsumen tentunya akan menambah tingginya kepercayaan konsumen terhadap suatu produk dan akan menciptakan ikatan di antara merek dengan konsumen tersebut. Hal ini dikarenakan brand personality bisa berguna untuk menganalisis perilaku atas suatu produk maupun pilihan merek (Suddin Lada, et,al, 2014).

Hasil penelitian Rismawati (2012) dan dan Djaya (2012) dalam menunjukkan bahwa terdapat hubungan yang positif dan signifikan antara brand personality dengan 
brand trust. Hal tersebut juga didukung dengan penelitian Mulyadi dan Saktiawati (2013) dan Yasri dan Sylvia (2014) bahwa berbagi pengetahuan mempunyai pengaruh positif terhadap brand trust.

$\mathrm{H}_{2}$ : Brand personality berpengaruh terhadap brand trust

\section{Pengaruh Brand Community terhadap Brand Trust}

Komunitas konsumen terhadap suatu merek tergambar dari kedekatan dan perhatian konsumen terhadap merek yang disebabkan karena tingginya kepercayaan konsumen terhadap merek tersebut. Komunitas merek dapat memperkuat pemahaman anggotanya yang disebabkan kepercayaan yang tinggi terhadap merek. Anggota komunitas tentu akan lebih dekat karena tingginya kepercayaan sehingga memperkuat fanatisme, materialism dan hedonism merek terhadap merek tersebut (Muniz dan O'quinn, 2001 dalam Atmaja dan Rachmawaty (2016)).

Hasil penelitian Purbaningtyas (2009) menunjukkan bahwa komunitas merek mempunyai pengaruh yang positif terhadap brand trust. Hasil penelitian Sismanto (2015) juga menunjukkan hal serupa bahwa brand community berperan besar dalam meningkatkan brand trust.

$\mathrm{H}_{3}$ : Brand community berpengaruh terhadap brand trust

\section{Pengaruh Brand Experience terhadap Brand Loyalty}

Konsumen akan loyal terhadap suatu merek produk yaitu dengan menguji pengalaman-pengalaman konsumen itu sendiri dan bagaimana pengalaman itu menghasilkan pendapat sikap, dan aspek lainnya dari perilaku konsumen. Oleh sebab itu pengalaman (experience) konsumen dalam berinteraksi dengan suatu merek menjadi sangat penting dalam menambah nilai merek itu sendiri agar konsumen loyal. Semakin tinggi konsumen mempunyai pengalaman dalam menggunakan suatu merek produk, tentu akan semakin menambah tingginya konsumen untuk tetap loyal (Brakus, et.al 2009 dalam Kusuma, 2014). Hal tersebut juga diperkuat dengan penelitian Ramaseshan dan Stein (2014) bahwa terdapat hubungan yang kuat antara Brand experience dengan brand loyalty, yaitu dengan arah positif.

Penelitian tentang Brand experience pernah dilakukan oleh beberapa peneliti, seperti yang dilakukan pada Kusuma (2014) yang menyatakan jika brand ezperience berperan besar dalam mempengaruhi brand loyalty. Lebih lanjut Ramaseshan dan Stein (2014) dan Azize Sahin et al (2011) juga terbukti bahwa Brand experience berperan besar dalam mempengaruhi tingginya brand loyalty. Mengacu pada teori dan didukung penelitian terdahulu, dapat dirumuskan hipotesis sebagai berikut:

$\mathrm{H}_{4}$ : Brand experience berpengaruh terhadap brand loyalty

\section{Pengaruh Brand Personality terhadap Brand Loyalty}

Kepribadian Merek (Brand Personality) memainkan peran penting dalam keberhasilan sebuah merek. Hal itu menyebabkan pelanggan turut merasakan kepribadian merek dan mengembangkan hubungan yang kuat (loyal) dengan merek. Sebuah kepribadian merek harus dibentuk menjadi tahan lama dan konsisten. Selain itu juga kepribadian merek harus memiliki kriteria yang berbeda dari merek lain dalam memenuhi tuntutan konsumen (Kumar et al., 2006). Kotler \& Amstrong (2012) menjelaskan dasar pemikiran dari brand loyalty adalah bahwa baik merek maupun manusia memiliki kepribadian, dan manusia sebagai konsumen cenderung memilih merek dengan kepribadian yang sesuai dengan kepribadiannya.

Pengaruh positif brand personality terhadap loyalitas pelanggan dikemukakan oleh Gobe (2005) yang menjelaskan bahwa merek-merek dengan brand personality yang kuat memiliki daya tarik yang kuat pula, 
daya tarik yang dapat dimanfaatkan untuk menciptakan ikatan emosional sehingga pelanggan merasa dekat dengan merek dan menganggap suatu merek tertentu sebagai bagian aktifitas hidupnya. Dengan tercipta ikatan emosional yang tinggi, pelanggan tidak akan mudah berganti merek karena pelanggan menjadi loyal terhadap merek tersebut (Suddin Lada, et,al, 2014).

Hasil penelitian penelitian Suddin Lada, et,al (2014) bahwa brand personality mempunyai pengaruh positif terhadap brand loyalty. Sedangkan penelitian Mulyadi dan Saktiawati (2013) dan Yasri dan Sylvia (2014) juga menyatakan bahwa brand personality mempunyai pengaruh terhadap loyalitas pelanggan. Berdasarkan teori dan penelitian terdahulu, maka dapat dirumuskan hipotesis:

\section{$\mathrm{H}_{5}$ : Brand personality berpengaruh terhadap brand loyalty}

\section{Pengaruh Brand Community terhadap Brand Loyalty}

Muniz dan O'quinn (2005) menjelaskan bahwa anggota komunitas merasa lebih memahami terhadap merek produk karena terlebih dahulu membandingkan dengan merek pesaing. Anggota komunitas juga memperlihatkan bagaimana kedekatan, kekhawatiran dan sekaligus kemarahan mereka terhadap pesaing. Anggota komunitas sering menolak produk yang ditawarkan pesaing karena tingginya loyalitas mereka walaupun produk itu memiliki reputasi yang lebih tinggi. Komunitas merek tergambar kedekatan dan perhatian konsumen terhadap merek karena merasakan loyal, sehingga anggota akan memperlihatkan komitmen mereka terhadap merek tersebut. Komunitas merek dapat memperkuat loyalitas seseorang sehingga mereka berusaha untuk bersikap fanatisme, materialisme dan hedonisme terhadap merek yang bersangkutan (Muniz dan O'quinn, 2001 dalam Atmaja dan Rachmawaty (2016)).

Hasil penelitian Purbaningtyas (2009) menyatakan bahwa brand community mempunyai pengaruh terhadap brand loyalty, yaitu dengan arah positif. Begitu halnya dengan penelitian Yasri, dkk (2014) menyatakan bahwa brand community juga berpengaruh positif terhadap loyalitas pelanggan.

$\mathrm{H}_{6}$ : Brand community berpengaruh terhadap brand loyalty

\section{Pengaruh Brand Trust terhadap Brand Loyalty}

Kepercayaan (trust atau belief) merupakan keyakinan bahwa tindakan orang lain atau suatu kelompok konsisten dengan kepercayaan mereka (Debholkar dalam Junusi, 2009). Masyarakat kini semakin selektif dalam memilih suatu merek produk. Kepercayaan konsumen terhadap suatu merek memainkan peran sekunder dalam mempengaruhi loyalitas. Penjelasan tersebut di dukung oleh Aacker dalam Sitinjak (2005) bahwa kepercayaan konsumen pada produk merupakan suatu kesan menyeluruh dari apa yang orang pikirkan dan ketahui tentang suatu produk sehingga kepercayaan terhadap produk banyak berkaitan dengan keyakinan, yakni bagaimana konsumen mempercayai bahwa suatu produk berada ditangga teratas dalam tingkatan produk. Haubl (1996) mengemukakan bahwa brand trust akan berpengaruh langsung terhadap tingginya loyalitas konsumen terhadap suatu produk. Lebih lanjut Gaeff (1996) yang menyatakan bahwa perkembangan pasar yang demikian pesat, dibutuhkan kepercayaan dari konsumen sehingga menuntut perusahaan mengupayakan lebih agar konsumen memutuskan pembelian dalam jangka panjang, dengan mendorong konsumen untuk lebih memperhatikan brand trust dibandingkan karakteristik fisik suatu produk dalam memutuskan pembelian.

Hasil penelitian Lestari, dkk (2015), Subiyanto (2014) menunjukkan bahwa brand trust mempunyai pengaruh terhadap loyalitas pelanggan. Hal tersebut juga didukung dengan penelitian Hendriyanto 
(2012) yang menjelaskan bahwa hubungan antara brand trust dengan loyalitas pelanggan adalah mempunyai arah yang positif.

$\mathrm{H}_{7}$ : Brand trust berpengaruh terhadap brand loyalty

\section{Model Empirik Penelitian}

Berdasarkan tujuan penelitian dan landasan teori, maka rumusan masalah yang telah diuraikan sebelumnya. Untuk mengetahui keterikatan pengaruh antar variabel penelitian, maka dapat dijelaskan pada model konseptual pada variabel penelitian dalam kerangka pemikiran teoritis berikut ini:

\section{METODE PENELITIAN}

\section{Populasi dan Sampel}

Populasi adalah adanya adalah para konsumen yang pernah membeli produk Oriflame di Semarang, dengan jumlah sampel sebesar 100 responden.

Teknik pengambilan sampel yang digunakan dalam penelitian ini adalah Convenience sampling atau kemudahan, yaitu elemen populasi (orang atau kejadian) yang datanya mudah diperoleh peneliti dengan tidak terbatas, sehingga peneliti memiliki kebebasan untuk memilih sampel yang paling cepat dan murah. (Indriantoro dan Supomo, 2012).

\section{Metode Analisis Data}

Metode analisa data dilakukan dengan uji analisis kuantitatif dengan alat analisis adalah Path analisis dimana sebelumnya dilakukan uji validitas dan reliabilitas serta uji persyaratan asumsi klasik. Hasil pengujian menunjukkan bahwa semua indicator pada masing-masing variable penelitian valid dan reliabilitas dan pengujian juga telah memenuhi persyaratan asumsi klasik. Adapun persamaan regresinya dapat ditulis sebagai berikut:

$Y_{1}: \beta_{1} X_{1}+\beta_{2} X_{2}+\beta_{3} X_{3}+e_{1}$

$Y_{2}: \beta_{1} X_{1}+\beta_{2} X_{2}+\beta_{3} X_{3}+\beta_{4} Y_{1}+e_{2}$

Keterangan :

$\mathrm{Y}_{1}$ : Brand trust

$\mathrm{Y}_{2}$ : Brand loyalty

$\mathrm{X}_{1}$ : Brand experience

$\mathrm{X}_{2}$ : Brand personality

$\mathrm{X}_{3}$ : Brand community

$\beta$ : Koefisien regresi

\section{HASIL PENELITIAN DAN PEMBAHASAN Path Analysis}

Tabel 1. Hasil Persamaan Regresi

\begin{tabular}{|l|l|l|l|l|}
\hline Variabel & B & t & Sig & Ket. \\
& & & & \\
\hline $\mathrm{X}_{1} \rightarrow \mathrm{Y}_{1}$ & 0,221 & 2,511 & 0,014 & $\mathrm{H}_{1}$ diterima \\
$\mathrm{X}_{2} \rightarrow \mathrm{Y}_{1}$ & 0,298 & 3,466 & 0,001 & $\mathrm{H}_{2}$ diterima \\
$\mathrm{X}_{3} \rightarrow \mathrm{Y}_{1}$ & 0,415 & 4,408 & 0,000 & $\mathrm{H}_{3}$ diterima \\
\hline $\mathrm{X}_{1} \rightarrow \mathrm{Y}_{2}$ & 0,177 & 2,510 & 0,014 & $\mathrm{H}_{4}^{3}$ diterima \\
$\mathrm{X}_{2} \rightarrow \mathrm{Y}_{2}$ & 0,246 & 3,474 & 0,001 & $\mathrm{H}_{5}$ diterima \\
$\mathrm{X}_{3} \rightarrow \mathrm{Y}_{2}$ & 0,376 & 4,690 & 0,000 & $\mathrm{H}_{6}$ diterima \\
$\mathrm{Y}_{1} \rightarrow \mathrm{Y}_{2}$ & 0,206 & 2,597 & 0,011 & $\mathrm{H}_{7}$ diterima \\
\hline
\end{tabular}

Pengujian Hipotesis

Dalam pengujian hipotesis akan dijelaskan pengaruh brand experience, brand personality, brand community terhadap brand loyalty dengan brand trust sebagai variabel intervening, seperti dijelaskan pada pengujian berikut ini:

\section{Pengaruh Brand Experience Terhadap Brand Trust}

Hasil pengujian brand experience terhadap brand trust diperoleh nilai t hitung sebesar 2,511 dengan nilai signifikansi sebesar $0,014<0,05$. Pada taraf signifikansi sebesar 0,05 dan degres of freedom (df) 
sebesar 96, maka diperoleh nilai $t$ tabel sebesar 1,9850, sehingga nilai $t$ hitung sebesar 2,511> 1,9850 yang berarti Ho ditolak dan $\mathrm{Ha}$ diterima. Hasil tersebut dapat diartikan bahwa pengujian mampu menerima hipotesis pertama, yang berarti bahwa terdapat pengaruh positif dan signifikan antara brand experience terhadap brand trust. Dengan hasil pengujian tersebut dapat disimpulkan bahwa dugaan adanya pengaruh antara brand experience terhadap brand trust i terbukti atau dapat diterima.

\section{Pengaruh Brand Personality terhadap Brand Trust}

Hasil pengujian brand personality terhadap brand trust diperoleh nilai $\mathrm{t}$ tabel sebesar 3,466 dengan nilai signifikansi sebesar $0,001<0,05$, sehingga nilai t hitung $=3,466$ telah melebihi dari nilai $\mathrm{t}$ tabel $=$ 1,9850 yang berarti Ho ditolak dan $\mathrm{Ha}$ diterima. Hasil tersebut maka dapat diartikan jika brand personality mempunyai pengaruh positif terhadap brand trust. Berdasarkan hasil pengujian dapat disimpulkan bahwa pengujian mampu menerima hipotesis kedua, sehingga dugaan adanya pengaruh brand personality terhadap brand trust terbukti atau dapat diterima.

\section{Pengaruh Brand Community terhadap Brand Trust}

Hasil pengujian brand community terhadap brand trust diperoleh nilai t hitung sebesar 4,408 dengan nilai signifikansi sebesar $0,000<0,05$, sehingga nilai t hitung $=4,408>$ nilai $t$ tabel 1,9850 yang berarti $\mathrm{Ho}$ ditolak dan Ha diterima. Penjelasan tersebut dapat diartikan bahwa brand community berpengaruh positif signifikan terhadap brand trust. Berdasarkan hasil pengujian dapat disimpulkan bahwa pengujian tersebut mampu menerima hipotesis ketiga, sehingga dugaan tersebut dapat diterima atau terbukti.

\section{Pengaruh Brand Experience terhadap Brand Loyalty}

Hasil pengujian brand experience terhadap brand loyalty diperoleh. nilai t hitung sebesar 2,510 dengan nilai signifikansi sebesar 0,014 $<0,05$. Pada taraf signifikansi 0,05 dan degres of freedom (df) sebesar 95, maka diperoleh nilai t tabel sebesar 1,9853, sehingga nilai $\mathrm{t}$ hitung = 2,510 > 1,9853 yang berarti Ho ditolak dan Ha diteirma memberikan pengertian bahwa brand experience mempunyai pengaruh positif terhadap brand loyalty. Hasil pengujian dapat disimpulkan jika pengujian mampu menerima hipotesis keempat, sehingga dugaan yang menyatakan adanya pengaruh positif antara brand experience terhadap brand loyalty terbukti atau dapat diterima.

\section{Pengaruh Brand Personality terhadap Brand Loyalty}

Hasil pengujian brand personality terhadap brand loyalty diperoleh nilai t hitung sebesar 3,474 dengan nilai signifikansi sebesar $0,001<$ tingkat kesalahan sebesar 0,05 . Dengan demikian nilai t hitung sebesar 3,474 telah melebihi dari nilai t tabel sebesar 1,9853. Dengan hasil tersebut maka dapat diartikan bahwa brand personality mempunyai pengaruh positif terhadap brand loyalty. Dengan demikian hasil pengujian tersebut mampu menerima hipotesis kelima, sehingga dugaan yang menyatakan adanya pengaruh brand personality terhadap brand loyaltya tersebut terbukti atau dapat diterima.

\section{Pengaruh Brand Community terhadap Brand Loyalty}

Hasil pengujian brand community terhadap brand loyalty diperoleh nilai t hitung sebesar 4,690 dengan nilai signifikansi sebesar $0,000<0,05$. Dengan demikian nilai t hitung 4,690 telah melebihi dari nilai $t$ tabel sebesar 1,9853 yang berarti Ho ditolak dan Ha diterima. Hasil pengujian tersebut dapat diartikan jika pengujian mampu menerima hipotesis keenam, dapat diartikan jika brand community mempunyai 
pengaruh positif dan signifikan terhadap brand loyalty. Berdasarkan hasil pengujian dapat disimpulkan bahwa dugaan adanya pengaruh brand community terhadap brand loyalty terbukti atau dapat diterima.

\section{Pengaruh Brand Trust terhadap Brand Loyalty}

Hasil pengujian brand trust terhadap brand loyalty diperoleh nilai t hitung sebesar 2,597 dengan nilai signifikansi sebesar $0,011<0,05$, sehingga nilai thitung sebesar 2,597 telah melebihi dari nilai $t$ tabel sebesar 1,9853 yang berarti Ho ditolak dan $\mathrm{Ha}$ diteirma. Penjelasan tersebut dapat diartikan bahwa brand trust mempunyai pengaruh positif dan signifikan terhadap brand loyalty. Berdasarkan hasil pengujian dapat disimpulkan bahwa pengujian mampu menerima hipotesis ketujuh, sehingga dugaan adanya pengaruh brand trust terhadap brand loyalty terbukti atau dapat diterima..

Berdasarkan nilai koefisien determinasi antara brand experience, brand personality dan brand community terhadap brand trust yang ditunjukkan pada Tabel 4.14 diperoleh nilai sebesar 0,729, dapat diartikan bahwa brand trust mampu dijelaskan oleh ketiga variabel yaitu brand experience, brand personality dan brand community sebesar $72,9 \%$ sedangkan sisanya dijelaskan oleh variabel lain yang tidak diamati dalam penelitian ini.
Pada model 2, yaitu pengaruh langsung menunjukkan bahwa nilai koefisien determinasi antara brand experience, brand personality, brand community dan brand trust terhadap brand loyalty ditunjukkan dengan nilai Adjusted $R$ Square sebesar 0,836 , dapat diartikan bahwa brand loyalty mampu dijelaskan oleh keempat variabel yaitu brand experience, Brand personality , brand community dan brand trust sebesar $83,6 \%$ sedangkan sisanya dijelaskan oleh variabel lain yang tidak diamati dalam penelitian ini

\section{Uji Sobel Test}

\section{Pengaruh Brand Experience Terhadap} Brand Loyalty melalui Brand Trust

Hasil pengujian sobel test antara brand experience terhadap brand loyalty melalui brand trust diperoleh nilai test statisticnya sebesar 2,178, sedangkan pada two tailed probability diperoleh nilai signifikansi sebesar $0,029<i$ tingkat kesalahan sebesar 0,05 . Dengan hasil tersebut dapat diartikan bahwa brand trust mampu menjadi variabel intervening antara brand experience dengan brand loyalty.

\section{Pengaruh Brand Personality terhadap Brand Loyalty melalui Brand Trust}

Hasil pengujian sobel test diperoleh nilai test statisticnya sebesar 2,182 dengan two tailed probability sebesar $0,029<$ dari tingkat kesalahan sebesar 0,05 dapat

\section{Uji Koefisien Determinasi}

Tabel 2. Koefisien Determinasi

\begin{tabular}{|l|l|l|c|}
\hline Variabel & $\mathbf{R}$ & $\begin{array}{l}\mathbf{R} \\
\text { Square }\end{array}$ & $\begin{array}{l}\text { Adjusted } \\
\text { R Square }\end{array}$ \\
\hline $\begin{array}{l}\text { Brand experience, brand } \\
\text { personality dan brand } \\
\text { community terhadap brand } \\
\text { trust }\end{array}$ & 0,858 & 0,737 & 0,729 \\
\hline $\begin{array}{l}\text { Brand experience, brand } \\
\text { personality, brand } \\
\text { community dan brand trust } \\
\text { terhadap brand loyalty }\end{array}$ & 0,918 & 0,843 & 0,836 \\
\hline
\end{tabular}

Peran Brand Trust 
disimpulkan jika brand trust mampu menjadi variabel intervening antara brand personality terhadap brand loyalty.

\section{Pengaruh Brand Community terhadap Brand Loyalty melalui Brand Trust}

Hasil pengujian sobel test antara brand community terhadap brand loyalty dengan brand trust sebagai variabel intervening diperoleh nilai test statisticnya sebesar 2,323 , sedangkan pada two tailed probability diperoleh signifikansi sebesar 0,020 0,05. Penjelasan tersebut dapat disimpulkan bahwa brand trust mampu menjadi variabel intervening antara brand community dengan brand loyalty.

\section{Pembahasan \\ Pengaruh Brand Experience terhadap Brand Trust}

Brand experience terbukti berpengaruh positif signifikan terhadap brand trust, dapat diartikan bahwa semakin tinggi pengalaman konsumen dalam menggunakan merek Oriflame, maka akan semakin menambah tingginya kepercayaan konsumen terhadap merek tersebut. Kepercayaan konsumen muncul karena konsumen telah berpengalaman menggunakan produk tersebut, sehingga konsumen akan merasakan (sensorik) tentang kelebihankelebihan yang dimiliki produk tersebut. Apalagi jika pelanggan merasakan kecocokan setelah menggunakan produk tersebut maka tentu akan mempengaruhi suasana hati, perasaan dan emosi dari konsumen (afeksi) untuk lebih mempercayai lagi pada merek produk tersebut.

Kepercayaan konsumen akan tumbuh jika produk tersebut aman untuk digunakan, maka tentu akan mengubah perilaku konsumen untuk menggunakan produk tersebut. Kepercayaan konsumen terhadap suatu produk juga dipengaruhi oleh intelektual konsumen, dimana konsumen akan berusaha melakukan pemikiran dengan seksama mengenai keberadaan merek produk tersebut melalui majalah khusus (katalog). Artinya bahwa konsumen yang mempunyai intelektual yang tinggi akan berusaha memilih produk yang berkualitas dan kecocokan dengan melihat kelebihan-kelebihan yang tersedia pada majalah khsus (katalog).

Menurut Siahaan (2011) bahwa kepercayaan konsumen terhadap merek memiliki hubungan personal yang tinggi terhadap suatu merek produk karena pengalamannya selama menggunakan produk tersebut sesuai dengan yang diharapkan. Brand experience akan semakin berkesan apabila memiliki perbedaan dari competitor, dan disampaikan dengan jelas. Brand experience akan menjadi sumber bagi konsumen atas terciptanya brand trust dan hal ini akan mempengaruhi brand loyalty (Ferrinadewi, 2008). Hasil penelitian ini mendukung hasil temuan penelitian Puspitasari (2015) menyatakan bahwa Brand experience berpengaruh positif terhadap brand trust. Hasil penelitian serupa juga dilakukan oleh Dewanti, dkk (2010) dan Lodjo (2013) yang menyatakan bahwa brand experience berpengaruh terhadap brand trust produk. Penelitian ini tidak mendukung hasil temuan Ramaseshan dan Stein (2014) bahwa brand experience tidak berpengaruh terhadap brand trust.

\section{Pengaruh Brand Personality terhadap Brand Trust}

Hasil penelitian menunjukkan brand personality berpengaruh positif terhadap brand trust, memberikan pengertian bahwa semakin tinggi brand personality, maka merek produk tersebut akan semakin memiliki daya tarik yang kuat bagi konsumen sehingga akan semakin meningkatkan kepercayaan konsumen terhadap merek tersebut. Untuk itulah penting bagi perusahaan untuk mengupayakan agar konsumen mempunyai semangat yang tinggi untuk memakai produk sehingga akan menumbuhkan tingginya kepercayaan dalam diri konsumen.

Kepercayaan konsumen akan tinggi 
jika produk kecantikan yang ditawarkan memiliki kecocokan dengan kulit konsumen. Jika produk yang dihasilkan sesuai dengan yang diharapkan konsumen karena memiliki kecocokan tentu akan semakin menambah tingginya kepercayaan konsumen. Disamping itu kepercayaan konsumen akan muncul jika dilihat dari fisiknya seperti kemasan produk kecantikan tersebut sangat ekslusif. Sebelum melakukan pembelian tentu konsumen akan melihat kemasan dari produk tersebut. Jika kemasan produk tersebut terlihat eksklusif, tentu akan semakin menambah tingginya kepercayaan konsumen pada merek produk tersebut.

Merek yang memiliki brand personality yang unggul dan sesuai dengan personality konsumen tentunya akan menambah tingginya kepercayaan konsumen terhadap suatu produk dan akan menciptakan ikatan di antara merek dengan konsumen tersebut. Hal ini dikarenakan brand personality bisa berguna untuk menganalisis perilaku atas suatu produk maupun pilihan merek (Suddin Lada, et,al, 2014). Hasil penelitian ini mendukung hasil temuan Rismawati (2012) dan dan Djaya (2012) bahwa terdapat hubungan yang positif dan signifikan antara brand personality dengan brand trust. $\mathrm{Hal}$ tersebut juga didukung penelitian Mulyadi dan Saktiawati (2013) dan Yasri dan Sylvia (2014) bahwa brand personality mempunyai pengaruh positif terhadap brand trust. Akan tetapi penelitian ini tidak mendukung hasil temuan Brody dan Cunningham, 1968; Enggel, et al, (1969) bahwa brand personality tidak memiliki pengaruh kuat dalam mempengaruhi brand trust dan brand loyalty.

\section{Pengaruh Brand Community terhadap Brand Trust}

Hasil pengujian menunjukkan bahwa brand community mempunyai pengaruh positif terhadap brand trust, memberikan pengertian bahwa semakin tinggi brand community, maka semakin konsumen dapat memperkuat pemahaman anggotanya yang disebabkan kepercayaan yang tinggi terhadap merek Oriflame, sehingga akan semakin meningkatkan tingkat kepercayaan konsumen terhadap merek tersebut. Untuk itulah penting bagi perusahaan dalam memperjuangkan para komunitas yang menyukai pada merek tertentu. Jika konsumen merasalah perbedaan setelah menjadi komunitas produk Oriflame bila dibandingkan dengan sebelum menjadi komunitas tentu akan semakin menambah tingginya kepercayaan konsumen pada merek produk tersebut.

Bagi konsumen yang tergabung dalam komunitas pada merek tertentu, tentu akan berusaha untuk bertukar pengalaman atau saling berbagi cerita dengan menceritakan kelebihan-kelebihan yang diberikan pada merek produk tersebut. Hal tersebut dilakukan sebagai bentuk tingginya kepercayaan konsumen pada merek tersebut. Untuk itulah penting bagi pihak perusahaan untuk terus melakukan evaluasi dalam meyakinkan pelanggan karena anggota yang tergabung dalam komunitas tentu akan berusaha untuk bertanggung jawab secara moral dalam menyebarkan kelebihan-kelebihan pada produk yang digunakan.

Menurut pernyataan Muniz dan O'quinn (2001)dalamAtmaja dan Rachmawaty (2016) bahwa komunitas merek dapat memperkuat pemahaman anggotanya yang disebabkan kepercayaan yang tinggi terhadap merek. Anggota komunitas tentu akan lebih dekat karena tingginya kepercayaan sehingga memperkuat fanatisme, materialism dan hedonism merek terhadap merek tersebut. Penelitian ini mendukung hasil temuan Purbaningtyas (2009) dan Sismanto (2015) bahwa komunitas merek mempunyai pengaruh yang positif terhadap brand trust. Akan tetapi hasil temuan ini tidak mendukung hasil temuan Dewi dan Sampurno (2015) bahwa brand community tidak berpengaruh terhadap brand trust.

Pengaruh Brand Experience terhadap 


\section{Brand Loyalty}

Hasil pengujian brand experience berpengaruh positif terhadap brand loyalty, dapat diartikan bahwa semakin tinggi pengalaman konsumen dalam menggunakan merek Oriflame, maka tentu akan semakin meningkatkan loyalitas pelanggan pada merek tersebut. Konsumen akan loyal jika mereka telah sering menggunakan (pengalaman positif) sehingga konsumen akan merasakan (sensorik) tentang kelebihan-kelebihan yang dimiliki produk tersebut. Apalagi jika pelanggan merasakan kecocokan setelah menggunakan produk tersebut maka tentu akan mempengaruhi suasana hati, perasaan dan emosi dari konsumen (afeksi) untuk lebih loyal menggunakan merek produk tersebut.

Untuk itulah penting bagi pihak perusahaan dalam mengevaluasi terhadap produk-produk yang dikeluarkan karena jika produk tersebut aman untuk digunakan, maka tentu akan mengubah perilaku konsumen untuk menggunakan produk tersebut. Loyalitas konsumen terhadap suatu produk juga dipengaruhi oleh intelektual konsumen, dimana konsumen akan berusaha melakukan pemikiran dengan seksama mengenai keberadaan merek produk tersebut melalui majalah khusus (katalog). Artinya bahwa konsumen yang mempunyai intelektual yang tinggi akan berusaha memilih produk yang berkualitas dan kecocokan dengan melihat kelebihan-kelebihan yang tersedia pada majalah khusus (katalog).

Brakus, et.al (2009) dalam Kusuma, 2014) menjelaskan bahwa experience konsumen mampu berinteraksi dengan merek menjadi sangat penting dalam menambah nilai merek itu sendiri karena mempunyai pengalaman dalam menggunakan suatu merek akan semakin menambah tingginya konsumen untuk tetap loyal. Penelitian ini mendukung hasil temuan Kusuma (2014) bahwa brand ezperience berperan besar dalam mempengaruhi brand loyalty. Sedangkan Ramaseshan dan Stein (2014) dan Azize Sahin et al (2011) juga terbukti bahwa Brand experience berperan besar dalam mempengaruhi tingginya brand loyalty. Akan tetapi hasil penelitian ini tidak mendukung hasil temuan Ramaseshan dan Stein (2014) bahwa brand experience justru tidak berpengaruh terhadap brand loyalty.

\section{Pengaruh Brand Personality terhadap Brand loyalty}

Brand personality terbukti berpengaruh positif terhadap brand loyalty, dapat diartikan bahwa semakin tinggi brand personality, maka merek produk tersebut akan semakin memiliki daya tarik yang kuat bagi konsumen sehingga akan berdampak pada tingginya loyalitas konsumen pada merek tersebut. Peran penting perusahaan sangat diperlukan dengan memberikan kelebihan-kelebihan pada produk tersebut, sehingga akan membuat konsumen tetap loyal menggunakan produk tersebut.

Konsumen akan loyal jika produk kecantikan yang ditawarkan memiliki kecocokan dengan kulit konsumen. Jika produk yang dihasilkan sesuai dengan yang diharapkan konsumen karena memiliki kecocokan tentu akan semakin menambah tingginya loyalitas konsumen. Tumbuhnya loyalitas konsumen juga dipengaruhi karena kemasan produk kecantikan tersebut sangat ekslusif. Kemasan dari produk sangat mempunyai pengaruh besar dalam menentukan konsumen dalam pemilihan suatu produk. Jika kemasan produk tersebut terlihat eksklusif, tentu akan merangsang konsumen untuk tetap menggunakan produk tesebut.

Kotler \& Amstrong (2012) menjelaskan dasar pemikiran dari brand loyalty adalah bahwa baik merek maupun manusia memiliki kepribadian, dan manusia sebagai konsumen cenderung memilih merek dengan kepribadian yang sesuai dengan kepribadiannya. Penelitian ini mendukung hasil temuan Ramaseshan dan Stein (2014), Mulyadi dan Saktiawati (2013) dan Yasri 
dan Sylvia (2014) menyatakan jika brand personality berpengaruh terhadap brand loyalty. Suddin Lada, et,al (2014) bahwa brand personality mempunyai pengaruh positif terhadap brand loyalty. Akan tetapi penelitian ini tidak mendukung hasil temuan Dewi dan Sampurno (2015) bahwa brand personality tidak berpengaruh terhadap brand loyalty.

\section{Pengaruh Brand Community terhadap Brand Loyalty}

Hasil pengujian terbukti bahwa brand community berpengaruh positif terhadap brand loyalty, dapat diartikan bahwa semakin tinggi brand community, maka semakin konsumen dapat memperkuat pemahaman anggotanya yang disebabkan kepercayaan yang tinggi terhadap merek Oriflame sehingga hal itu akan berdampak pada tingginya loyalitas konsumen pada merek tersebut. Untuk itulah penting bagi perusahaan dalam memperjuangkan para komunitas yang menyukai pada merek tertentu agar tetap loyal pada produk yang ditawarkan. Jika konsumen merasalah perbedaan setelah menjadi komunitas produk Oriflame bila dibandingkan dengan sebelum menjadi komunitas tentu akan semakin menambah tingginya loyalitas konsumen pada merek produk tersebut.

Bagi konsumen yang tergabung dalam komunitas pada merek tertentu, tentu akan berusaha untuk bertukar pengalaman atau saling berbagi cerita sebagai bentuk tingginya loyalitas pada merek tersebut yaitu dengan menceritakan tentang kelebihankelebihan yang diberikan pada merek produk tersebut. Untuk itulah penting bagi pihak perusahaan untuk terus melakukan evaluasi dalam meyakinkan pelanggan karena anggota yang tergabung dalam komunitas merupakan asset bagi perusahaan karena anggota komunitas tentu akan berusaha untuk bertanggung jawab secara moral dalam menyebarkan kelebihan-kelebihan pada produk yang digunakan.

Komunitas merek dapat memperkuat loyalitas seseorang sehingga mereka berusaha untuk bersikap fanatisme, materialisme dan hedonisme terhadap merek yang bersangkutan (Muniz dan O'quinn, 2001 dalam Atmaja dan Rachmawaty (2016)). Penelitian ini mendukung hasil temuan Purbaningtyas (2009), Denkala dan Tricahyono (2016) dan Yasri, dkk (2014) bahwa brand community mempunyai pengaruh terhadap brand loyalty, yaitu dengan arah positif. Penelitian ini tidak mendukung hasil temuan Ramadhania dan Suryadi (2011) bahwa komunitas merek tidak berpengaruh terhadap loyalitas merek

\section{Pengaruh Brand Trust terhadap Brand Loyalty}

Hasil pengujian menunjukkan bahwa brand trust mempunyai pengaruh signifikan positif terhadap brand loyalty, memberikan pengertian bahwa semakin tinggi tingkat kepercayaan konsumen pada merek Oriflame, maka akan mempengaruhi tingginya loyalitas pelanggan terhadap merek tersebut. Konsumen akan loyal jika produk yang digunakan tersebut memiliki kelebihan-kelebihan bila dibandingkan dengan produk kecantikan lainnya.

Untuk itulah penting bagi perusahaan untuk menjaga reputasi terhadap merekmerek yang sudah menjadi kepercayaan konsumen, karena reputasi yang baik terhadap merek tersebut akan membuat konsumen berusaha untuk melakukan pembelian dalam jangka panjang. Apalagi jika konsumen tidak pernah merasakan pengalaman buruk selama menggunakan produk kecantikan, tentu akan semakin menambah tingginya loyalitas konsumen pada merek produk tersebut.

Gaeff (1996) menjelaskan bahwa perkembangan pasar yang demikian pesat, dibutuhkan kepercayaan dari konsumen sehingga menuntut perusahaan mengupayakan lebih agar konsumen memutuskan pembelian dalam jangka panjang. Penelitian ini mendukung hasil temuan Atmaja dan Rachmawaty (2016), 
Lestari, dkk (2015), Subiyanto (2014) bahwa brand trust mempunyai pengaruh terhadap loyalitas pelanggan. Hal tersebut juga didukung dengan penelitian Hendriyanto (2012) dan Dewi dan Sampurno (2015) yang menjelaskan bahwa hubungan antara brand trust dengan loyalitas pelanggan adalah mempunyai arah yang positif.

\section{Pengaruh Langsung dan Tidak Langsung}

Berdasarkan hasil pengujian sobel test, terlihat bahwa brand trust mampu menjadi variabel intervening antara brand experience dengan brand loyalty. Penjelasan tersebut dapat diartikan bahwa semakin tinggi pengalaman konsumen dalam menggunakan merek Oriflame, maka akan semakin menambah tingginya kepercayaan konsumen terhadap merek tersebut sehingga hal itu akan berdampak pada tingginya loyalitas pelanggan. Dengan demikian loyalitas pelanggan dapat meningkat dibutuhkan suatu pengalaman dari pelanggan pada produk Oriflame sehingga pelanggan tersebut akan memunculkan kepercayaan pada merek tersebut.

Brand trust mampu menjadi variabel intervening antara brand personality terhadap brand loyalty, memberikan pengertian bahwa semakin tinggi brand personality, maka merek produk tersebut akan semakin memiliki daya tarik yang kuat bagi konsumen sehingga akan semakin meningkatkan kepercayaan sehingga hal itu tentu akan semakin menambah tingginya loyalitas pelanggan terhadap merek tersebut. Dengan demikian loyalitas pelanggan akan meningkat jika merek tersebut tumbuh di dalam diri konsumen karena kuatnya kepercayaan konsumen pada merek tersebut.

Hasil pengujian juga menunjukkan jika brand trust mampu menjadi variabel intervening antara brand community dengan repurchase, dapat diartikan bahwa semakin tinggi brand community, maka semakin konsumen dapat memperkuat pemahaman anggotanya yang disebabkan kepercayaan yang tinggi terhadap merek Oriflame, sehingga akan semakin meningkatkan loyalitas pelanggan terhadap merek tersebut. Loyalitas pelanggan tumbuh disebabkan karena banyaknya komunitas yang menggunakan produk tersebut, sehingga memperkuat timbulnya kepercayaan konsumen pada merek yang digunakan.

\section{SIMPULAN}

Berdasarkan penelitian yang telah dilakukan maka dapat diperoleh kesimpulan sebagai berikut :

Brand experience terbukti berpengaruh positif terhadap brand trust, dapat diartikan bahwa semakin tinggi pengalaman konsumen dalam menggunakan merek Oriflame, maka akan semakin menambah tingginya kepercayaan konsumen terhadap merek tersebut.

Brand personality berpengaruh positif terhadap brand trust, memberikan pengertian bahwa semakin tinggi brand personality, maka merek produk tersebut akan semakin memiliki daya tarik yang kuat bagi konsumen sehingga akan semakin meningkatkan kepercayaan konsumen terhadap merek tersebut.

Brand community berpengaruh positif terhadap brand trust, memberikan pengertian bahwa semakin tinggi brand community, maka semakin konsumen dapat memperkuat pemahaman anggotanya yang disebabkan kepercayaan yang tinggi terhadap merek Oriflame, sehingga akan semakin meningkatkan tingkat kepercayaan konsumen terhadap merek tersebut.

Brand experience berpengaruh positif terhadap brand loyalty, dapat diartikan bahwa semakin tinggi pengalaman konsumen dalam menggunakan merek Oriflame, maka tentu akan semakin meningkatkan loyalitas pelanggan pada merek tersebut.

Brand personality mempunyai pengaruh positif terhadap brand loyalty, memberikan pengertian bahwa semakin tinggi brand 
personality, maka merek produk tersebut akan semakin memiliki daya tarik yang kuat bagi konsumen sehingga akan berdampak pada tingginya loyalitas konsumen pada merek tersebut.

Brand community berpengaruh positif terhadap brand loyalty, dapat diartikan bahwa semakin tinggi brand community, maka semakin konsumen dapat memperkuat pemahaman anggotanya yang disebabkan kepercayaan yang tinggi terhadap merek Oriflame sehingga hal itu akan berdampak pada tingginya loyalitas konsumen pada merek tersebut.

Brand trust mempunyai pengaruh positif terhadap brand loyalty, memberikan pengertian bahwa semakin tinggi tingkat kepercayaan konsumen pada merek Oriflame, maka akan mempengaruhi tingginya loyalitas pelanggan terhadap merek tersebut.

Brand trust mampu menjadi variabel intervening antara brand experience dengan brand loyalty, artinya semakin tinggi pengalaman konsumen dalam menggunakan merek Oriflame, maka akan semakin menambah tingginya kepercayaan konsumen terhadap merek tersebut sehingga hal itu akan berdampak pada tingginya loyalitas pelanggan.

Brand trust mampu menjadi variabel intervening antara brand personality dengan brand loyalty, artinya semakin tinggi brand personality, maka merek produk tersebut akan semakin memiliki daya tarik yang kuat bagi konsumen sehingga akan semakin meningkatkan kepercayaan sehingga hal itu tentu akan semakin menambah tingginya loyalitas pelanggan terhadap merek tersebut.

Brand trust mampu menjadi variabel intervening antara brand community terhadap repurchase artinya semakin tinggi brand community, maka semakin konsumen dapat memperkuat pemahaman anggotanya yang disebabkan kepercayaan yang tinggi terhadap merek Oriflame, sehingga akan semakin meningkatkan loyalitas pelanggan terhadap merek tersebut.

Atas dasar kesimpulan yang telah dikemukakan di atas, dapat diberikan beberapa saran dan diharapkan dapat berguna bagi kemajuan perusahaan. Adapun beberapa saran tersebut adalah :

Brand community merupakan faktor yang paling dominan dalam mempengaruhi brand loyalty, sehingga penting bagi perusahaan untuk menggandeng para komunitas Oriflame dengan sebaik-baiknya, karena para komunitas merek juga merupakan ujung tombak dalam memasarkan produk disebabkan karena komunitas merek mempunyai tanggung jawab moral yang tinggi terhadap merek yang digunakan..

Dalam upaya menumbuhkan semangat yang tinggi terhadap produk Oriflame maka penting bagi pihak manajemen perusahaan untuk meyakinkan kepada para pelanggan selaku konsultan untuk lebih mengenal tentang kelebihan-kelebihan yang ditawarkan pada produk Oriflame.

Dalam upaya meningkatkan kepercayaan pelanggan, maka produk yang ditawarkan lebih ditingkatkan lagi dengan melakukan inovasi sehingga produk tersebut mempunyai kelebihan-kelebihan sehingga menarik perhatian pelanggan.

Brand experience merupakan variabel yang paling terlemah dalam meningkatkan loyalitas pelanggan, sehingga perlu ada upaya dari pihak perusahaan untuk memberikan sesuatu yang lebih kepada produk yang ditawarkan sehingga konsumen dapat merasakan secara langsung setelah menggunakan produk tersebut.

Penelitian ini hanya dilakukan pada pelanggan satu merek produk Oriflame yang tentunya tidak bisa digeneralisasi untuk obyek yang baku atau digeneralisasi di obyek penelitian lain dan variabel yang digunakan dalam penelitian ini hanya 3 (tiga) variabel endogen yang mempengaruhi brand loyalty, yaitu brand experience, brand personality, brand community. Untuk itu sebaiknya pada 
penelitian selanjutnya perlu memperluas obyek penelitian seperti penelitian yang dilakukan pada merek produk kecantikan yang beredar di masyarakat dan sangat dikenal agar dapat mencerminkan kondisi penelitian secara keseluruhan dan perlunya menambah variabel penelitian, seperti inovasi, orientasi pasar, orientasi pelanggan, evaluasi pembelajaran dan lain-lain

\section{DAFTAR PUSTAKA}

Aziz, sahin. (2011). The effect of Brand Experiences, Trust and Satisfaction on building Brand Loyalty; An Empirical Research On Global Brands.

Brakus, J.J., Schmitt, B.H \& Zarantonello, L. (2009. )"Brand Experience : What is it? How is it Meassured? Does it Affect Loyalty?. Journal of Marketing.

Griffin, Jill. (2012). Customer Loyalty terjemahan Dwi Kartini Yahya. Jakarta: Erlanga.

Gobe, Marc. (2005). Emotional Branding. Jakarta: Erlangga.

Indriantoro, Nur dan Supomo, Bambang. (2002). Metodologi Penelitian Bisnis (Untuk Akuntansi dan Manajemen), Edisi Pertama, BPFE - UGM : Yogyakarta.

Kotler, P., \& Armstrong, G. (2012). Principles of Markering. New Jersey: Prentice Hall International.

Kotler, Philip and Keller, Kevin Lane. (2009). Marketing Management 13th Edition. Singapore: Prentice Hall.

Kumar, R., Luthra, A. and Datta, G. (2006). Linkages between brand personality and brand loyalty: a qualitative study in an emerging market in the Indian context. South Asian Journal of Management.

Kusuma, Yohanes Surya. (2014). Pengaruh brand experience terhadap brand loyalty melalui brand satisfaction dan brand trust Harley Davidson di Surabaya. Jurnal manajemen pemasaran.

Lau, Tiger, dan Lee J Calantone. (1999). The Impact of Market Knowledge Competence on New Product Advantage : Cocceptualization and Empirical Examination. Journal of Marketing.

Mulyadi dan Saktiawati. (2013). Pengaruh personality merek dan komunitas merek terhadap loyalitas merek. Jurnal Kajian Manajemen Bisnis.

Oliver, Richard L. (2009). Satisfaction : A. Behavioral Perspective on The Consumer, Mc Graw - Hill : New York.

Ramaseshan, B dan Alisha Stein. (2014). Connecting The Dots Between Brand Experience And Brand Loyalty : The Mediating Role Of Brand Personality And Brand Relationship. Journal of Brand Management.

Rangkuti, Freddy. (2012). The Power of Brands. Jakarta, PT Gramedia Pustaka Utama.

Siahaan, Saor Mardongan. (2011). Pengaruh Persepsi Nilai Konsumen Terhadap Brand Loyalty Private Label Carrefour Plaza Medan Fair. Jurnal manajemen Bisnis Universitas Sumatera Utara, Medan.

Suddin, Lada, et.al. (2014). Moderating role of product involvement on the relationship between brand personality and brand loyalty. Journal of Internet Banking and Commerce.

Tjiptono, Fandy. (2012). Strategi Pemasaran, Edisi Kedua, Cetakan Kelima. Penerbit Andi : Yogyakarta.

Tjiptono, Fandy. (2014). Service Quality \& Statisfaction, Edisi Ketiga, Andi Ofset : Yogyakarta.

Umar, Husien. (2003). Metodologi Penelitian : Aplikasi dalam Pemasaran, PT. Gramedia Pustaka Utama : Jakarta. 